\title{
Alinhando à tese de Charles Goodwin: "o afásico é um falante competente que não pode falar"1
}

\author{
Lívia Miranda de Oliveira² \\ Julia Gonçalves Dias ${ }^{3}$ \\ Ingrid Santos Leite ${ }^{4}$ \\ Universidade Federal de Sergipe, São Cristóvão, Sergipe, Brasil
}

\begin{abstract}
Resumo: Este estudo objetivou investigar a competência pragmático-interacional de um sujeito afásico, partindo de dados naturais de fala em interação e alinhando-se à tese de Charles Goodwin de que afásicos são falantes competentes que não podem falar. Nele, elegemos olhar para a performance de um sujeito afásico via estratégias discursivas por ele engenhosamente utilizadas para dar conta da comunicação com o outro. Para dar suporte às nossas escolhas teóricas e metodológicas, recorremos aos fundamentos do campo da Linguística Sociointeracional, área que se caracteriza por articular diferentes tradições de pesquisa, como a AC, a Linguística, a Antropologia (etnografia), a Sociologia, a Filosofia (Pragmática) (cf. Gumperz 1982). Seguindo esse caminho, foi possível observar que o sujeito afásico se engajou proativamente na interação, empenhando-se muito (e colaborativamente) para que os seus interlocutores o compreendessem, e, assim, de um modo extremamente habilidoso, mostrou sua grande competência pragmáticointeracional em performances de um falante competente.
\end{abstract}

Palavras-chave: Linguagem; Interação; Afasia.

Title: Aligning with the thesis of Charles Goodwin: "the aphasic is a competent speaker who can't speak"

Abstract: This study aimed to investigate the pragmatic-interactional competence of an aphasic subject, starting from natural speech data in interaction and aligning with the thesis of Charles Goodwin that aphasics are competent speakers who cannot speak. In it, we choose to look at the performance of an aphasic subject via discursive strategies that he, ingeniously, used to deal with the communication with others. In order to support our theoretical and methodological choices, we recurred to the foundations of the field of Sociointerational Linguistics, a field characterized by articulating with different research traditions, such as Conversation Analysis, Linguistics, Anthropology (ethnography), Sociology and Philosophy (Pragmatic) (cf. Gumperz 1982). Following this way, it was

\footnotetext{
${ }^{1}$ Agradecemos imensamente à professora Dra Liliana Cabral Bastos pelo diálogo que muito contribuiu para o aprimoramento deste artigo e ao neurologista Dr Marcelo de Oliveira Ribeiro Paixão pela grande colaboração com a pesquisa desde 2016 através do encaminhamento de pacientes afásicos.

${ }^{2}$ Professora do curso de fonoaudiologia da Universidade Federal de Sergipe. ORCID:

https://orcid.org/0000-0001-8180-0242

E-mail: liviamirandaoliveira@yahoo.com.br

${ }^{3}$ Aluna do curso de fonoaudiologia da Universidade Federal de Sergipe e bolsista PIBIX (PROEX) 2017. ORCID: https://orcid.org/0000-0002-2267-815X

E-mail: fono.juliadias@gmail.com

${ }^{4}$ Aluna do curso de fonoaudiologia da Universidade Federal de Sergipe e bolsista PIBIC (COPES) 2018.

ORCID: https://orcid.org/0000-0002-8044-8045

E-mail: ingridleitecontato@gmail.com
} 
possible to observe that the aphasic subject proactively engaged in the interaction, working very hard (and collaboratively), so that his interlocutors could understand him, and, thus, in an extremely skillful way, showed his great pragmatic-interactional competence in performances of a competent speaker.

Keywords: Language; Interaction; Aphasia.

\title{
Introdução
}

\begin{abstract}
Como uma lesão, afasia reside dentro do crânio. No entanto, como forma de vida, modo de ser e agir no mundo em concerto com os outros, o seu locus próprio é um sistema endógeno, distribuído, multipartidário, dentro do qual a linguagem funciona como uma matriz socialmente organizada de prática pública (GOODWIN: $1943-2018)$.
\end{abstract}

No cenário nacional, na última década, observa-se um montante maior de estudos que buscam conhecer (e valorizam) as possibilidades comunicativas dos sujeitos afásicos em comparação a estudos que investigam os déficits linguísticos por eles apesentados, o que reflete um olhar mais amplo para as afasias e os afásicos. Essa tendência vai de encontro à visão tradicional, que, conforme Charles Goodwin (2002; p. 32) coloca, analisa a afasia como "um impedimento individual, algo alojado no indivíduo, que perde competências linguísticas cruciais tais como a habilidade de produzir unidades sintáticas". Goodwin, há aproximadamente três décadas, na Universidade da Califórnia em Los Angeles, vinha se aprofundando nas pesquisas em afasia a partir de um prisma interacional e defendendo que o afásico é um falante competente que não pode falar; nos termos do autor, "a competente speaker who can't speak" (cf. GOODWIN, 2004). Com o seu falecimento em março deste ano, ele deixa um grande legado à linguística e aos estudos sobre afasia. Em seus trabalhos, o autor nos propõe um novo olhar para os afásicos partindo do princípio de que o que é relevante na investigação da competência do afásico na construção de sentidos não se encontra confinado no seu cérebro, mas, ao invés, centra-se em suas habilidades pragmático-interacionais.

A proposta de realizarmos um estudo acerca da competência pragmático-interacional de sujeitos afásicos surgiu no segundo semestre do ano de 2017, quando vimos revelada, de um modo sobremaneira saliente nas interações terapêuticas, a expertise para se comunicar de um paciente afásico que integrava os projetos de pesquisa e extensão coordenados pela primeira autora e dos quais as demais autoras fazem parte. Nesse momento, foi principalmente aos trabalhos de Goodwin que recorremos como aporte teórico para tudo aquilo que vimos revelado nas interações ao longo daquele semestre.

Conforme fidedignamente destaca Bastos (2010) em um artigo que traz ao conhecimento do leitor a sua interlocução com Goodwin em um congresso brasileiro em 2010, o autor, em seus estudos, dedicava-se a observar cada olhar, gesto, expressão e movimento na sequência de ação, de modo que nenhum detalhe era desprezado. Não há como não 
concordar com Bastos (2010) que é fascinante o modo como o autor "documenta a sincronia dos múltiplos sistemas semióticos em funcionamento, a movimentação de corpos e olhares na dinâmica das interações cotidianas" (p. 99).

Destarte, ancorando-se teórico-metodologicamente na mesma vertente de estudos linguísticos em que se insere a análise sociointeracional do discurso Goodwin - a vertente de estudo da interação social - e articulando trabalhos de diferentes tradições de pesquisa afins (Análise da Conversa, Linguística, Antropologia, Sociologia e Pragmática), conforme propõe a Linguística Sociointeracional (cf. GUMPERZ, 1982), nos propomos a analisar as estratégias discursivas utilizadas pelo participante afásico em sua performance de falante competente.

No cenário nacional, especificamente no campo da Linguística Sociointeracional, Oliveira (cf. OLIVEIRA, DIAS, 2018; OLIVEIRA, BASTOS, 2015, 2014, 2012, 2011; OLIVEIRA, OLIVEIRA, 2014; OLIVEIRA, 2013; OLIVEIRA, 2009), elegendo diferentes categorias interacionais para análise de dados de fala naturalísticos (e de emergência espontânea a), vem desconstruindo a visão da incompetência de afásicos nas práticas com (e através de) a linguagem, que se centra na tradição milenar logocêntrica. $O$ fenômeno de investigação deste estudo específico é a performance do paciente afásico alcançada via um repertório de recursos semióticos multimodais. Portanto, versamos incialmente sobre fundamentos teóricos acerca das noções de competência (com o foco em um prisma externalista) e de performance (sob o prisma de estudos do campo da interação social), fazendo, ao final, uma articulação desses constructos antes de prosseguir para os aspectos metodológicos que, juntamente com os pressupostos teóricos, sustentam as análises das estratégias discursivas utilizadas pelo sujeito afásico em suas brilhantes performances.

\section{A competência a partir de uma perspectiva externalista}

Neste estudo, informado teórico-metodologicamente por perspectivas interacionais em linguística, que se situam na vertente pragmática de estudos linguísticos (aquela que concebe a linguagem como ação, práxis), o interesse está em entender o que a noção de competência ${ }^{5}$ nos informa acerca das nossas ações no mundo com (e através de) a linguagem. Portanto, o foco aqui se voltará para a visão externalista desse fenômeno.

Dell Hymes, antropólogo, estudioso do campo da etnografia da comunicação, foi o primeiro a incorporar as dimensões social e cultural à noção de competência fundada pelo gerativismo, mais especificamente por Noam Chomsky. $O$ autor nos apresenta a proposta de uma competência comunicativa, que abarcaria, além da competência linguística, a competência social, argumentando que a competência linguística é necessária, mas não suficiente para que o indivíduo possa usar a linguagem. Nesse sentido, enquanto a

\footnotetext{
${ }^{5}$ Para uma revisão de literatura acerca da noção de competência no campo da linguística, ver Morato (2008).
} 
competência linguística trataria de regras (internas inatas) sintático-semânticas do processamento cognitivo da linguagem, a competência social se ocuparia da descrição de regras (externas adquiridas) do uso social da linguagem.

Podemos considerar que Hymes abriu caminho para se repensar a questão da competência, introduzindo, nas reflexões acerca desse fenômeno, o indivíduo e suas intenções comunicativas, as funções sociais da linguagem, um saber construído no e através do uso da linguagem, nas práticas humanas (MORATO, 2008).

No que concerne à visão externalista, entender a competência em termos de "normas sociais" significa levar em conta os valores culturais que determinam essas "normas", esse conjunto de regras que subjazem a comunicação, as práticas sociais com (e através de) a linguagem e que se encontram refletidas nos discursos dos membros de diferentes culturas. Podemos relembrar, por exemplo, as regras que regem i) a tomada de turnos em conversas (cf. SACKS, SCHEGLOFF, JEFFERSON, 1974), ii) a sua organização sequencial (cf. SACKS, 1993), iii) o sistema de preferência nelas operantes (cf. SCHEGLOFF, 1995) e o iii) sistema de reparo conversacional (cf. SCHEGLOFF, JEFFERSON, SACKS, 1977). Fazendo uso do termo adotado por Garfinkel e Sacks ([1986] 2012), tais regras dizem algo da competência conversacional dos interactantes. Quando engajados em uma conversa, reconhecemos (mesmo que intuitivamente) a operacionalidade dessas regras, que são, de certo modo, impostas a nós enquanto membros de uma determinada cultura. Obedecer (ou agir conforme) tais regras faz parte da nossa competência social para operar com (e através de) a linguagem. Nas palavras de Coulon (1995a, p. 26),

para poderem se desenvolver, as nossas conversas são organizadas, respeitando uma ordem, que não temos necessidade de explicar durante $o$ decurso de nossas conversas, mas que é necessária para tornar inteligíveis as nossas conversas. Noutras palavras, demonstramos, no decorrer de nossas conversas, a nossa competência social para conversar com nossos semelhantes, de um lado, expondo, tornando compreensíveis aos outros os nossos comportamentos e, de outro lado, interpretando o comportamento dos outro.

Na condição de fator social, as "normas" variam de acordo com os contextos social, cultural, discursivo e interacional, que informam (todos eles) o processo interpretativo em análises que se ancoram na abordagem da Linguística Sociointeracional como as aqui empreendidas. Independentemente do tipo de atividade discursiva em que estamos engajados, estaremos sempre atendendo a regras impostas pelos valores da cultura na qual estamos inseridos, pois somos competentes não só para construir enunciados que se pautam em regras sintático-semânticas, mas sobretudo para usar tais enunciados do modo como nos orientam as regras sociais (competência social), sendo isso índice da nossa competência comunicativa enquanto indivíduos imersos em um sistema coercitivo de regras. 
Conforme Morato (2008, p. 61-62),

\begin{abstract}
mesmo sujeitos afásicos, que em tese teriam sua competência linguística comprometida ou contraída em função de uma lesão cerebral adquirida, não deixam - em suas ações e práticas com a linguagem - de atuarem de forma competente. Ao contrário, se não submetermos a concepção de competência a uma forma gramatical e individual da expressão verbal, baseada na distinção competência versus performance (reducionismo muito comum nas baterias-padrão de avaliação ou de testes diagnósticos de afasias), poderemos perceber que afásicos podem atuar com e sobre a linguagem de forma criativa, colaborativa e apropriada a seus propósitos conversacionais ou discursivos (MORATO, 2008; p. 61-62).
\end{abstract}

A partir, então, do prisma externalista, a competência se permite observar nas práticas com (e através de) a linguagem em situações interacionais, nos recursos e estratégias verbais e não-verbais empregadas pelos falantes, nas ações reflexivas dos indivíduos, entre outros. Assim sendo, ela não se limita ao verbal, abarcando diferentes recursos semióticos envolvidos nas variadas atividades discursivas. Em se tratando das práticas discursivas de pessoas com afasia, variados podem ser os recursos não-verbais a serviço de suas competências comunicativas, sendo tais recursos os alvos do nosso olhar investigativo aqui. Ressaltamos que, neste artigo, adotamos os termos competência conversacional, competência pragmático-interacional e competência comunicativa como intercambiáveis.

\title{
A competência refletida na performance dos atores sociais ${ }^{6}$
}

Embora as noções de competência e performance tenham tradicionalmente sido concebidas como distintas/ apartadas pelos gerativistas, neste estudo, propomos investigar a competência via performance, o que é possível quando se assume a existência de uma competência externa e não se reduz a performance ao uso da linguagem. Para tanto, adotaremos a visão de performance advinda da sociologia, mais especificamente, do clássico trabalho de Erving Goffman ([1959] 2008), intitulado A apresentação do eu na vida cotidiana. Nele, para falar de performance, o autor aborda o comportamento humano em situações sociais, utilizando a metáfora da ação teatral em que o mundo é um palco e os indivíduos são atores sociais.

Para um melhor entendimento da visão sociológica goffmaniana, cabe considerar incialmente que as ações de um indivíduo são realizadas levando-se em conta o seu interlocutor, de modo que, em situações interacionais, tais ações (verbais ou não) são moldadas pelos copresentes; afinal, “a interação (isto é, interação face a face) pode ser

\footnotetext{
${ }^{6}$ Esta seção, assim como a seção 3, abrangem uma parte da tese de doutorado da primeira autora, defendida no ano de 2013 na Pontifícia Universidade Católica do Rio de Janeiro e intitulada a Performance de pessoas com afasia na construção de narrativas em interações face a face em grupo.
} 
definida, em linhas gerais, como a influência recíproca dos indivíduos sobre as ações uns dos outros, quando em presença física imediata" (GOFFMAN [1959] 2008, p. 23).

Muitas são as fontes de informações e muitos são os veículos de indícios para transmissão de informações nas interações. Em outras palavras, muitos são os recursos que são índices das apresentações dos selves que compõem a cena interacional; entretanto, "muitos fatos decisivos estão além do lugar e do tempo da interação, ou dissimulados nela" e, portanto, os indivíduos "serão forçados a aceitar alguns acontecimentos como sinais convencionais ou naturais de algo não diretamente acessível aos sentidos" (GOFFMAN, [1959] 2008, p. 12).

Quanto ao processo de apresentações de selves, "quando uma pessoa chega à presença de outras, existe, em geral, alguma razão que a leva a atuar de forma a transmitir a elas a impressão que Ihe interessa transmitir" (GOFFMAN, [1959] 2008, p. 14). Todo esse processo é guiado por regras sociais que devem ser reconhecidas e levadas em conta pelos interactantes, tanto em suas apresentações como na interpretação das ações do outro. Dessa forma, "em todas as situações, até nas mais institucionalizadas e ritualizadas, as pessoas são agentes na produção dos seus próprios selves sociais e dos selves dos outros" (OCHS, 1993; p. 296), ao, conduzidas por regras sociais, projetarem uma ou outra imagem de si e interpretarem as projeções do outro.

De acordo com Goffman ([1959] 2008), o acesso ao outro (à imagem que o outro transmite de si) se dá por meio de expressões dadas (produções verbais) e expressões emitidas (produções não-verbais e presumivelmente não-intencionais), sendo estas últimas de um tipo teatral e contextual. Essa construção da imagem de si, essa performance teatral, ocorre no curso de eventos interacionais, sendo que, conforme advogam Jacoby e Ochs (1995), corroborando a exposição acima de Goffman, tais eventos não estão limitados a estruturas sintáticas, palavras, frases e orações que os interactantes podem enunciar. Ao contrário, direcionamento de olhar, expressão facial, gesto, movimento corporal, pitch, entonação, orientação a objetos no espaço interacional, riso, sobreposição e sua resolução, sílabas incompletas e suprimidas, e silêncio são extremamente relevantes na interação. Através de meios linguísticos, não-linguísticos e paraliguísticos, os interactantes exibem, reafirmam, questionam, mantêm, e modificam seus diversos selves como desdobramentos da fala turno-a-turno dando mostras de sua competência pragmático-interacional.

Destarte, ao expressar a imagem de si, na grande maioria das vezes, o indivíduo se apresenta sob uma luz favorável, o que é sustentado pelo princípio da "boa aparência" (cf. OCHS, CAPPS, 2001), e, para tanto, pode manipular a impressão que o outro terá dele por meio das expressões emitidas, projetando uma imagem que condiz com aquela projetada via expressões dadas. Com isso, "como os outros provavelmente não suspeitam, em termos relativos, do aspecto que se supõe não intencional da conduta do indivíduo, este pode ganhar muito controlando-o" (GOFFMAN, [1959] 2008, p. 17), já que existe essa possibilidade de os outros recorrerem a "aspectos considerados não-governáveis do comportamento expressivo do indivíduo como uma prova da validade do que é transmitido pelos aspectos governáveis" 
(p. 16).

Seguindo esta linha, "uma performance pode ser definida como toda atividade de um determinado participante, em dada ocasião, que sirva para influenciar, de algum modo, qualquer um dos outros participantes" (GOFFMAN, [1959] 2008, p. 23) e que, podemos acrescentar, conta com a competência pragmático-interacional dos participantes. Nesse sentido, o autor está considerando que quando uma pessoa está na presença de outras, existe, em geral, alguma razão que a leva a atuar de modo a transmitir a elas a impressão que lhe interessa transmitir. Desse modo, "se a atividade do indivíduo tem de tornar-se significativa para os outros, ele precisa mobilizá-la de modo tal que expresse, durante a interação, o que ele precisa transmitir" (GOFFMAN, [1959] 2008, p. 36) (grifos do original). Trata-se de uma realização dramatúrgica (um show do indivíduo), uma performance por meio da qual qualidades e atributos pretendidos pelo ator social são retoricamente projetados no curso da interação.

Nas interações sociais da vida cotidiana, se um indivíduo está engajado em um jogo de autoapresentação (apresentação do self, projeção do self), podemos concordar com Goffman que tal indivíduo, metaforicamente, é um ator social. Nas apresentações de selves, o ator social faz uso de recursos expressivos (itens do equipamento expressivo), sendo que alguns desses recursos acompanham o ator onde quer que ele vá (por exemplo, vestuário, sexo, idade, características raciais, altura, aparência), ao passo que outros são relativamente móveis ou transitórios (ex.: padrões de linguagem, expressões faciais, gestos corporais).

O self, como personagem representado, não se origina do seu possuidor, mas da cena de sua atuação - visão anti-essencialista/ construcionista, sendo, portanto, um efeito dramatúrgico construído por meio contingências dos acontecimentos locais. Isso é o mesmo que dizer que os selves são frutos de performances. Nas palavras de Goffman ([1959] 2008, p. 231), este self e seu corpo "fornecem o cabide no qual algo de uma construção colaborativa será pendurado por algum tempo. E os meios para produzir e manter os selves não residem no cabide", encontrando-se nas situações sociais, nas atuações de performance.

Sumarizando, então, deve-se ter em conta que como atores sociais que somos, estamos sempre engajados na performance de nossos selves, gerenciando as impressões que o outro possa ter deles, não obstante se cremos ou não em nossas atuações, tampouco se nosso interesse é iludir e/ ou envolver a plateia, sendo que tal performance faz parte da nossa competência pragmático-interacional. E, no que diz respeito a pessoas com afasia, elas não devem ser consideradas exclusas dessas performances, uma vez que, assim como defenderam Oliveira e Oliveira (2009, p.87), "a afasia não implica em perda da capacidade de interagir socialmente, seja participando de conversas, seja de qualquer outra atividade que demande competência social". 


\section{Situando a performance em um contexto sociocultural}

Quando um indivíduo se apresenta diante dos outros, sua performance tende a incorporar valores oficialmente reconhecidos pela sociedade, se consideramos a existência de uma matriz cultural de valores e crenças.

$\mathrm{Na}$ tentativa de entender a performance em sua relação com o contexto sociocultural em que ocorre, precisamos, como destaca Cicourel (1980), construir uma ponte entre microfenômenos, tais como discurso e interação social, e macronoções, tais como indicadores sociais, valores culturais dominantes e padrões de desigualdade na população. Podemos entender essa relevância por meio das palavras de Michael Moerman (1996 [1988], p. 02) através das quais o autor situa que "é na interação que as pessoas encontram, experiencializam e aprendem os princípios, as instituições e os ideais que caracterizam sua sociedade e cultura", sendo cultura "um conjunto - talvez um sistema - de princípios de interpretação, conjugado com os produtos desse sistema" (p. 04).

Acerca do contexto sociocultural, cabe considerar, por um lado, que interação e discurso juntos constituem o substrato das construções sociais, e, por outro, que a principal razão para o interesse em macronoções é que elas nos informam sobre experiências de vida reais e sobre quem estamos estudando. Tais alinhamentos nos possibilita sustentar que o discurso não é livre de valor, sendo histórico, cultural, social e biograficamente contextualizado, portanto, influenciado (e constituído) por questões macro, como por exemplo, valores culturais que não apenas constituem nossa cultura como também determinam nosso discurso. Nesse sentido, "qualquer coisa que é dita, é dita por alguém a alguém, em um momento particular de alguma ocasião específica, socialmente organizada e culturalmente informada" (MOERMAN, 1996 [1988], p. X, Prefácio).

Então, podemos melhor entender as performances de selves como processos informados por valores culturais, sendo o ator social um "depósito" de valores e princípios da cultura no qual está inserido. Os dispositivos de performance utilizados pelo ator social fazem parte de repertórios culturais, o que faz com que a interpretação de seus usos seja norteada por considerações acerca da estrutura social normativa sem, no entanto, negligenciar a performance individual.

O antropólogo Richard Bauman fala de performance em termos de manifestações culturais contextualizadas (cf. BAUMAN, 1986 [1988]). Assim considerando, não há como negligenciar o fato de que toda fala é encaixada nos contextos histórico, social e cultural de sua produção, de modo que tais contextos afetam o que é dito (logo, nenhuma fala é livre de valores). Conforme outrora mencionado, uma articulação desses diferentes contextos em análises interpretativistas é possibilitada pela abordagem da Linguística Sociointeracional aqui adotada.

Conforme bem coloca Moerman (1996 [1988], p. XI, Prefácio), "em toda ocasião de fala, as pessoas estão experiencializando e produzindo suas culturas, seus papéis e suas 
personalidades". Podemos, então, localizar certa reciprocidade nesse processo, visto que as pessoas, em suas ações discursivas, constroem valores culturais que, por sua vez, orientamnas nessas ações.

A partir de todas essas considerações, podemos sustentar que, de fato, linguagem, sociedade e cultura estão firmemente conectadas/ inter-relacionadas, guiando todo e qualquer processo performático. Tal posição nos permite entender as construções discursivas que emergem nas práticas com (e através de) a linguagem como situadas em um contexto sociocultural, portanto, orientadas por uma competência de ordem social, interacional e discursiva.

\section{Aspectos metodológicos}

O estudo aqui desenvolvido se insere no projeto de pesquisa intitulado Narrativa como instrumento de uma primeira investigação clínica das afasias, aprovado pelo comitê de ética em pesquisa da Universidade Federal de Sergipe sob o parecer de número 483.781 e coordenado pela primeira autora deste artigo. Esse projeto se insere no grupo de pesquisa Intervenção fonoaudiológica e multidisciplinar nos diferentes ciclos da vida, mais especificamente, na linha de pesquisa Intervenção fonoaudiológica com adultos e idosos.

Neste artigo específico, são analisados dados de fala em interação do senhor Hugo (pseudônimo), que, na ocasião do ingresso no projeto (em 2017), tinha 52 anos e se encontrava afastado da sua atividade laboral de marceneiro em decorrência do Acidente Vascular Encefálico (AVE) que o acometera fazia aproximadamente um mês, que havia deixado a afasia como única sequela. Ele chegou à clínica escola em que o projeto é desenvolvido acompanhado de seu filho, que falava por ele, já que, devido à severidade do seu quadro clínico, o único item lexical que ele produziu no primeiro encontro foi "xim" (em referência a sim), além de ter utilizado gestos com a cabeça indicativos de concordância e de discordância. No decorrer dos encontros do grupo terapêutico para afásicos, ocorreram outras produções linguísticas acompanhadas de manifestações patológicas no discurso oral do comprometimento por ele apresentado; entretanto, devido à perspectiva aqui assumida, que não tem a pretensão de investigar as produções linguísticas dos afásicos (o que invocaria análises textuais, mas não interacionais como as que realizamos), não cabe aqui apresentar uma caracterização da fala do sujeito afásico (com destaque para os déficits linguísticos) nem mesmo tipificar o comprometimento por ele apresentado (nas habilidades de expressão e compreensão). Assim sendo, iremos nos reportar a aspectos estruturais da linguagem do senhor Hugo e às manifestações patológicas apenas quando tais aspectos e manifestações se tornarem relevantes no turno a turno da interação.

Após a apresentação do projeto e a leitura do Termo de Consentimento Livre e Esclarecido para ambos, senhor Hugo foi convidado a retornar na semana seguinte para a realização de uma entrevista inicial e uma avaliação, que definiriam sua elegibilidade ou não 
para participação do projeto, levando-se em conta o único critério de exclusão da pesquisa comprometimento severo da compreensão verbal que impossibilite a interação com o outro. Uma vez que o senhor Hugo apresentava incialmente apenas um leve comprometimento da compreensão verbal em circunstâncias em que frases de extensões mais longas foram utilizadas por seus interlocutores, ele passou a integrar o projeto e, com isso, a participar dos encontros semanais do grupo terapêutico de afásicos. Nesses encontros, de ocorrência semanal e de duração de noventa minutos, eram realizadas atividades que oportunizavam o engajamento dos pacientes em práticas discursivas bem como eram valorizadas quaisquer formas de comunicação que partissem deles. Atividades como narrativas pessoais, conversas, discussão de reportagens lidas e assistidas nos encontros, discussão de assuntos que circulavam na mídia naquelas ocasiões e pequenas narrativas (como por exemplo, narrar alguma atividade cotidiana), entre outras, compunham os encontros, que eram gravados em vídeo e/ ou áudio e, mediante interesse de investigação, eram transcritos para análise com base nas convenções propostas por Gail Jefferson (cf. SACKS, SCHEGLOFF, JEFFERSON, [2003] 1974) com adaptações de autores da área da interação, como Schiffrin (1987) e Tannen (1989).

Desde a primeira participação do senhor Hugo no grupo de afásicos, ele se mostrou bastante proativo nas tentativas de se comunicar com os demais membros do grupo, que era composto por afásicos, por discentes do curso de fonoaudiologia e pela docente pesquisadora. Mesmo diante de suas limitações linguísticas (em termos de expressão verbal) decorrentes do AVE, ele nunca recusava os espaços a ele concedidos para se expressar e, através do seu engajamento nas interações, foi nos revelando uma grande habilidade pragmático-interacional de recorrer a diversos recursos alternativos à fala para tentar se comunicar. Sua grande expertise saltou aos nossos olhos e nos motivou a investigar, de um modo mais aprofundado, a sua competência para se comunicar com outro, sendo este artigo um fruto dessas investigações. Para isso, recorremos a aportes teóricos e metodológicos do campo dos estudos linguísticos da interação social e elegemos investigar as estratégias discursivas à serviço da grande performance do senhor Hugo de falante competente. Assim, nos debruçamos em interessantes análises de fala em interação, que serão apresentadas a seguir e que, com certeza, irão levar o leitor a olhar de um novo modo para pessoas que são afásicas (quando estão falando), mas que também são muito mais que isso, conforme podem nos anunciar os selves por elas projetados nas interações sociais.

\section{Análises de dados naturais de fala em interação}

Participam das interações sob análise a fonoaudióloga e docente cujo pseudônimo é Lúcia, os terapeutas discentes para os quais foram escolhidos os pseudônimos Jânia, Jair e Leonora, e pacientes afásicos, sendo que, conforme acima mencionado, o paciente afásico cujas falas serão aqui analisadas recebeu o pseudônimo de Hugo. Os três excertos analisados 
consistem em: (i) uma conversa espontânea sobre a data de nascimento de Hugo, que foi iniciada com o propósito, por um lado, de fornecer aos demais pacientes mais informações sobre o novo integrante do grupo e, por outro, de oportunizar seu engajamento na interação e em práticas discursivas (excerto 1); (ii) discussão sobre um assunto que estava circulando na mídia naquela ocasião - a Copa Libertadores da América (excerto 2); e (iii) conversa espontânea desencadeada por uma pequena narrativa que a antecede sobre as atividades e alimentações que o paciente tinha realizado naquele dia (excerto 3 ).

Com o objetivo de investigar a performance de Hugo como falante competente, tornada relevante em todas as interações em que ele participou, lançamos nosso olhar para os diversos recursos multimodais por ele utilizados. Cada excerto traz em sua identificação as estratégias discursivas imbricadas na construção de sentidos nas interações sob análise.

Excerto 1, trecho 1: recursos gráficos e gestos

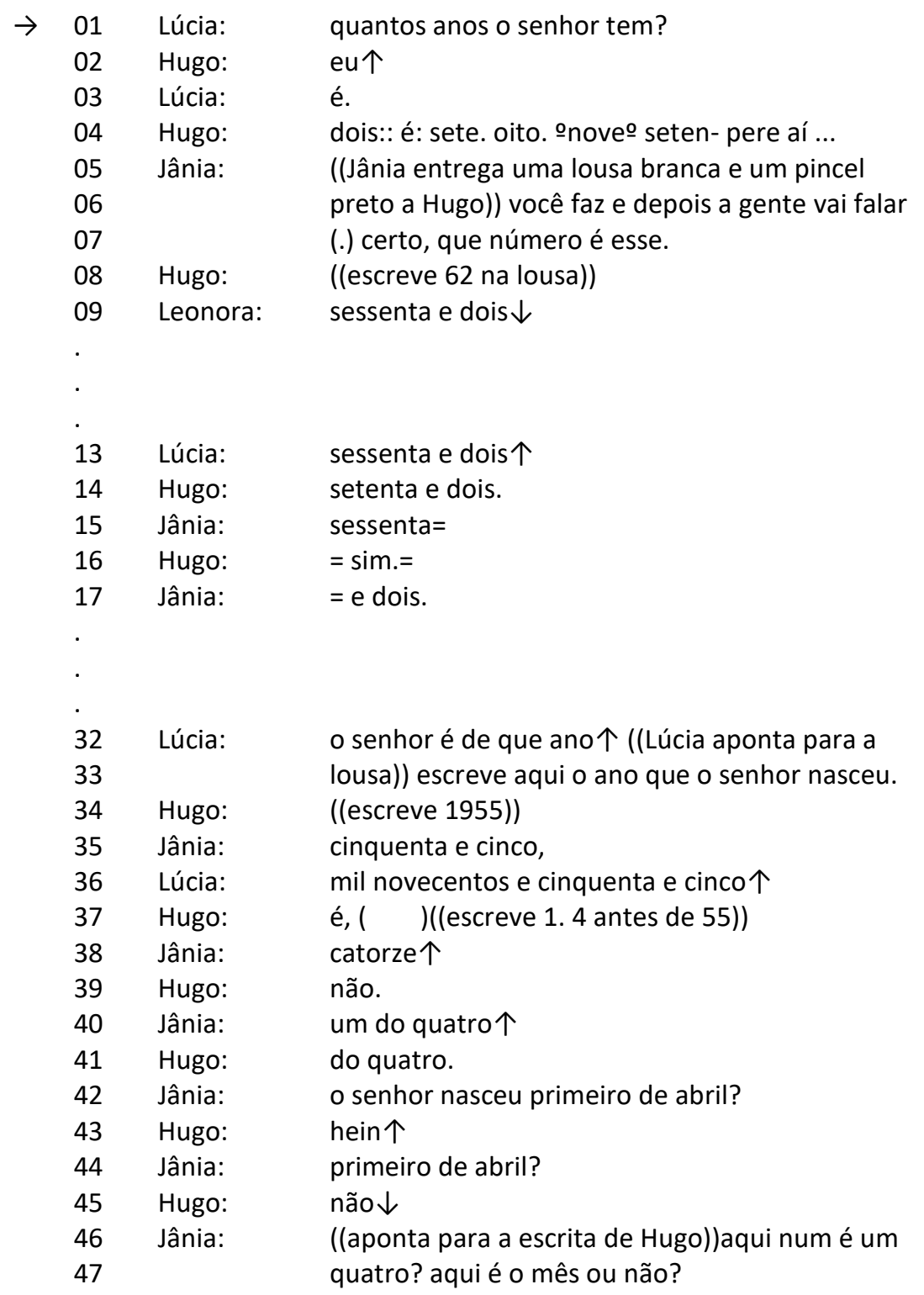




\begin{tabular}{|c|c|c|}
\hline 48 & Hugo: & não, ali.((aponta para o número 1)) \\
\hline 49 & Jânia: & é o quê? \\
\hline 50 & Hugo: & ali. é: quatro. aqui: aqui é o: \\
\hline 51 & Jânia: & um $\downarrow$ \\
\hline 52 & Hugo: & é: o: \\
\hline & & \\
\hline • & & \\
\hline 62 & Lúcia. & dia guatrô \\
\hline 63 & Hugo: & sim, \\
\hline 64 & Lúcia: & de janeiro个 \\
\hline 65 & Hugo: & sim, \\
\hline 66 & Jânia: & ah::: \\
\hline
\end{tabular}

O excerto acima consiste em um pequeno trecho do segundo mês em que Hugo compareceu aos encontros semanais do grupo de afásicos. Nele, Lúcia, inicia a interação perguntando a Hugo qual a sua idade na linha 1 ("quantos anos o senhor têm?"). A resposta de Hugo começa a ser construída na linha 4: "dois:: é: sete. oito. onoveo seten- ( ) pere aí". Diante da dificuldade de Hugo em elaborar seu enunciado de resposta, Jânia, conhecendo suas limitações linguísticas bem como suas possibilidades comunicativas, entregou-lhe uma lousa branca e um pincel preto para que ele pudesse se expressar graficamente e assegurou a ele que iria contribuir na construção da resposta: "você faz e depois a gente vai falar(.) certo, que número é esse.", linhas 06 e 07 . Hugo pegou a lousa e escreveu o número 62, que foi parafraseado verbalmente por Leonora no turno seguinte ("sessenta e dois $\downarrow$ "). Após algumas tentativas de Hugo de, sob mediação terapêutica, proferir sessenta e dois (trecho que foi extraído deste excerto), Lívia, na linha 13, solicita a confirmação da parte de Hugo acerca da paráfrase de Leonora - "sessenta e dois $\uparrow "$ - que é realizada na linha 16 - "sim.".

Nesse trecho da interação, podemos verificar o turno a turno da construção colaborativa de sentido, na qual se engajam terapeutas e o paciente afásico, e o sucesso na conclusão desse processo, não obstante se os recursos expressivos utilizados pelo paciente não tenha se restringido à fala. É relevante destacar que as terapeutas, ao possibilitarem (e até mesmo proporem) o uso de recursos alternativos à fala para a construção de sentido, exibem uma postura que valoriza as diversas semioses envolvidas na comunicação de pacientes afásicos e que assume como foco terapêutico a comunicação e não a fala, legitimando competências que abrangem em seu domínio muito além da estrutura da língua.

Ainda valendo-se da habilidade de expressão gráfica de Hugo, Lúcia, na linha 32, o questiona quanto ao ano em que ele nasceu ("o senhor é de que ano $\uparrow$ ") e, em seguida, na linha 33, solicita que ele escreva tal ano na lousa ("escreve aqui o ano que o senhor nasceu."). De posse da lousa, Hugo escreve o número 55 e, em seguida, é indagado por Lívia quanto à correspondência verbal da sua expressão não verbal ("mil novecentos e cinquenta e cinco个") na linha 36. Não satisfeito em informar apenas o ano do seu nascimento, em uma postura proativa, escreve 1. 4 antes do número 55; produção escrita esta que é interpretada por Jânia na linha 38 ("catorze个") e reparada por Hugo na linha 39 através de uma ação que inicia um 
reparo ("não") (cf. SCHEGLOFF, JEFFERSON, SACKS, 1977). Diante dessa iniciação de um reparo, Jânia fornece uma nova tradução para a expressão gráfica de Hugo ("um do quatro个") - linha 40, que se configura como a finalização do reparo e que é então confirmada por ele ao repetir a tradução de Jânia ("do quatro.") na linha 41 - recibo do reparo.

Não obstante Hugo ter confirmado (através do recibo) o reparo que Jânia levou a cabo, o sucesso na construção do sentido acerca da sua data de nascimento só ocorreu apenas após algumas trocas de turno, quando as interlocutoras inferiram que na sua produção escrita (1. 4. 55), o primeiro número referia-se ao mês em que ele nasceu (1), o segundo referia-se ao dia (4) e o terceiro referia-se ao ano (1955), chegando à conclusão que a data de nascimento de Hugo era dia quatro de janeiro de mil novecentos e cinquenta e cinco. $O$ alcance da intersubjetividade nesse trecho da interação se deu através da semiose de recursos gráficos (números escritos na lousa), não verbais (gestos de apontar para o número ao qual se fazia referência) e verbais (fala das interlocutoras na tradução da expressão gráfica de Hugo). Os recursos não verbais atuaram como pisas de contextualização (cf. GUMPERZ, 1998) que dispararam a inferência final (cf. GUMPERZ, 1999) expressa verbalmente pelas interlocutoras. Ademais, gestos de apontar são concebidos como ações bastante significativas em conversas com afásicos, sendo usados de várias maneiras como um recurso interacional (KLIPPI, 2015).

\section{Excerto 1, trecho 2: apoio no discurso do interlocutor e pista fonêmica}

\begin{tabular}{|c|c|c|}
\hline 67 & Lúcia: & dia quatro de janeiro $\downarrow$ eu sou de cinco de janeiro $\downarrow$ \\
\hline 68 & Hugo: & isso. \\
\hline 69 & Lúcia: & eu sou de cinco de janeiro (.) que eu nasci. \\
\hline 70 & Jânia: & e eu sou dia primeiro. \\
\hline 71 & Leonora: & e eu sou dia dez. \\
\hline 72 & Jânia: & todo mundo de janeiro (.) eu sou dia primeiro, ela \\
\hline 73 & & dia dez e ela dia cinco. \\
\hline 74 & Hugo: & oxente, \\
\hline 75 & Lúcia: & fazer uma festa né, senhor Hugo $\uparrow$ \\
\hline 76 & Hugo: & é: como é:个 \\
\hline 77 & Jânia: & ano个 \\
\hline 78 & Hugo: & quanto个 \\
\hline 79 & Jânia: & meu个 \\
\hline 80 & Hugo: & não, cinco. \\
\hline 81 & Jânia: & primeiro (.) eu sou primeiro. \\
\hline 82 & Hugo: & não. cin:co o:: \\
\hline 83 & Lúcia: & o mês个 \\
\hline 84 & Hugo: & não. o: cinco, o cin:.co oomo é?o \\
\hline 85 & Lúcia: & o ano个 \\
\hline 86 & Hugo: & sim, agora. agora é o:: oomo é? como é que são, \\
\hline 87 & Lúcia: & [o dia个] \\
\hline 88 & Lúcia: & idade $\uparrow$ \\
\hline 89 & Hugo: & não, \\
\hline 90 & Jânia: & ano novo (.) eu nasci no ano, dia primeiro de \\
\hline 91 & & janeiro. \\
\hline 92 & Hugo: & sim, é por isso que você é do:: s. é:: oo que é \\
\hline 93 & & que eu queria dizer $\downarrow^{\circ}$ \\
\hline 94 & Jânia: & o quê个 \\
\hline
\end{tabular}




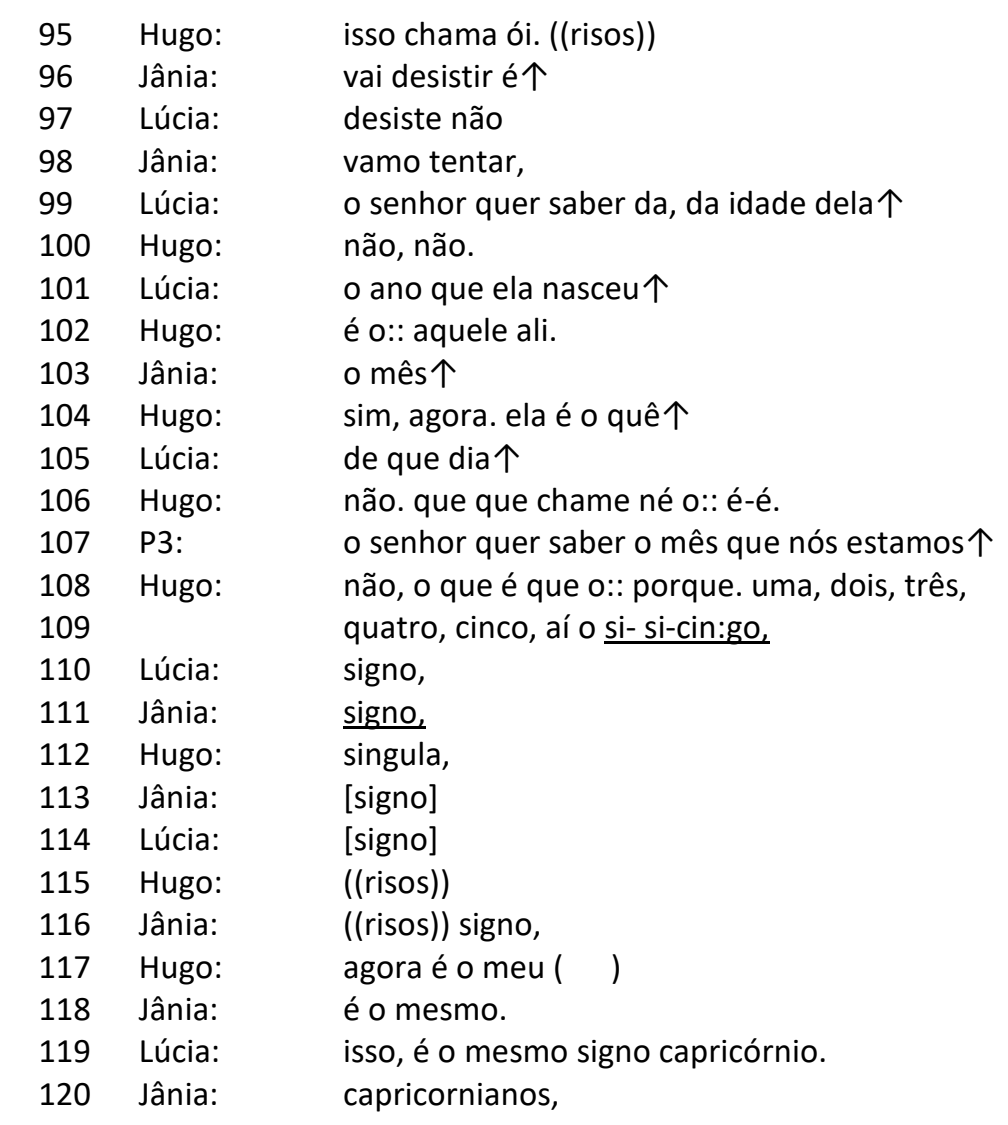

No excerto acima, após as terapeutas identificarem a coincidência de que ali naquele grupo haviam três terapeutas que também fazem aniversário em janeiro, assim como Hugo, ele se engajou na tentativa de acréscimo de informação adicional na linha 76 ("é: como é: $\uparrow$ "); ação esta que, novamente, sinaliza o caráter proativo da sua participação na interação, uma vez que ele, diante da sua dificuldade para se expressar verbalmente, poderia se acomodar e apenas ocupar a posição de segunda parte do par adjacente (SPP), por exemplo, apenas respondendo o que lhe for perguntado; no entanto, ele iniciou um novo tópico - falar sobre os signos. Diante de suas limitações linguísticas, ele não conseguiu elaborar seu enunciado e solicitou ajuda das terapeutas, que interviram com perguntas de verificação de entendimento até o turno da linha 84 em que Hugo, não satisfeito com as colaborações das terapeutas, tenta produzir um novo enunciado ("não. o: cinco, o cin:.co como é?o”). Novamente, as terapeutas não obtiveram sucesso na verificação dos seus entendimentos acerca do enunciado de Hugo; porém, a fala de Jânia nas linhas 90 e 91 ("ano novo (.) eu nasci no ano, dia primeiro de janeiro") serviu de apoio à fala seguinte de Hugo por fornecer a estrutura sintática a ela necessária (cf. GOODWIN, 2002). Ele, então, conectou a fala de Jânia à sua fala na linha 92 de um modo que o possibilitasse expressar o que pretendia ("sim, é por isso que você é do:: s:: é::"). Dessa forma, incorporando a fala do outro e a conectando à sua para alcançar seus propósitos comunicativos, pessoas com afasia encontram a possibilidade de se apresentarem como atores sociais (cf. GOODWIN, 2004). 
Ainda na linha 92, ao solicitar a cooperação da terapeuta para completar a sua fala diante da sua dificuldade de encontrar a palavra que almejava, Hugo proferiu apenas o som da letra s, possivelmente com a finalidade de que as terapeutas completassem a sua fala. Embora elas não tenham conseguido realizar nenhuma inferência a partir da produção de Hugo de um prompt fonêmico, ele não desistiu de se expressar mesmo diante de tamanha dificuldade e, dando mostras da sua expertise pragmático-interacional, nas linhas 108 e 109, forneceu uma grande contribuição para a inferência das terapeutas: ele valeu-se da preservação da linguagem automática, muito comum em casos de afasia, e proferiu a sequência numérica automática de um a cinco: "uma, dois, três, quatro, cinco, aí o cin- cin-cin:go,". É muito interessante observar que ele utilizou representação fonêmica da sílaba inicial da palavra cinco (/sî/) para fornecer uma pista auditiva às terapeutas que as possibilitasse inferir a palavra que ele queria dizer. Nesse caso, a linguagem automática favoreceu a sua expressão verbal, uma vez que ele utilizou o som da sílaba inicial da palavra cinco para produzir uma nova palavra que não mais fizesse parte da sequência automática que ele acabara de proferir. Interrompendo, então, a sequência numérica, ele fez uso de uma conjunção, que marcou sua transição da linguagem automática para uma nova construção. Após isso, repetiu duas vezes a sílaba "cin" e acrescentou a sílaba "go", possibilitando, assim, que, a partir da construção "cin:go", suas interlocutoras, tomando como base o contexto sequencial, alcançassem mais facilmente a palavra por ele almejada. A inferência foi construída pela a terapeuta Lúcia e explicitada logo a seguir na linha 110 ("signo"), trazendo grande satisfação a Hugo, conforme pode ser observado por seus risos subsequentes. Podemos assumir que o sucesso na coconstrução do sentido da fala de Hugo se deveu sobretudo ao trabalho inter-acional turno a turno que realça o seu grande empenho em se fazer entender, em não desistir diante das suas limitações estritamente linguísticas (em termos estruturais) e em buscar a cooperação do outro, mostrando conceber esse outro-terapeuta como um parceiro interacional. Sem sombra de dúvidas, a performance de Hugo na projeção de um self competente e proativo contou com a sua expertise pragmático-interacional.

\section{Excerto 2: gestos e contexto sequencial}

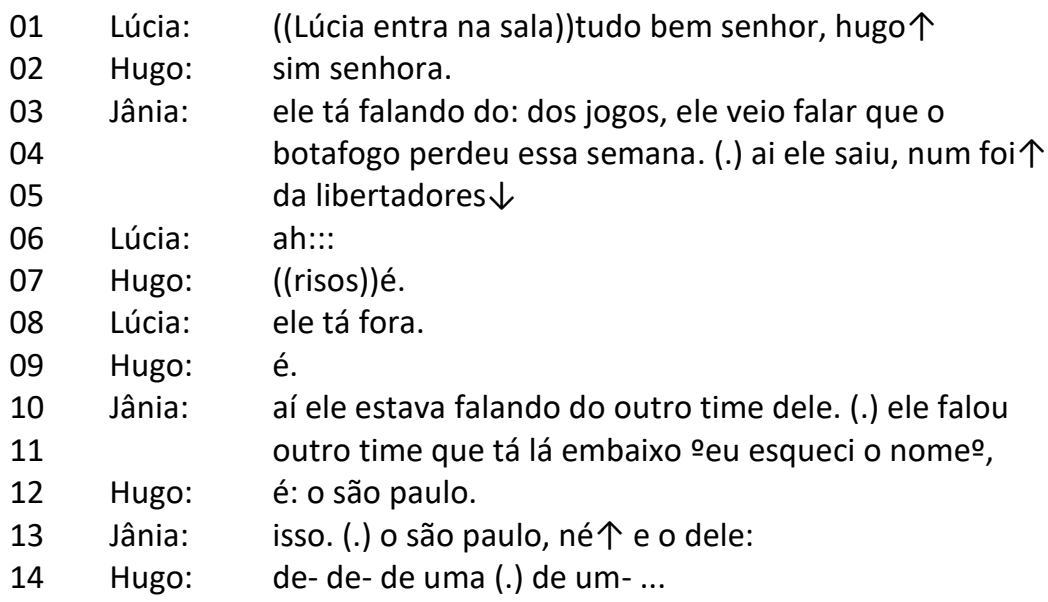




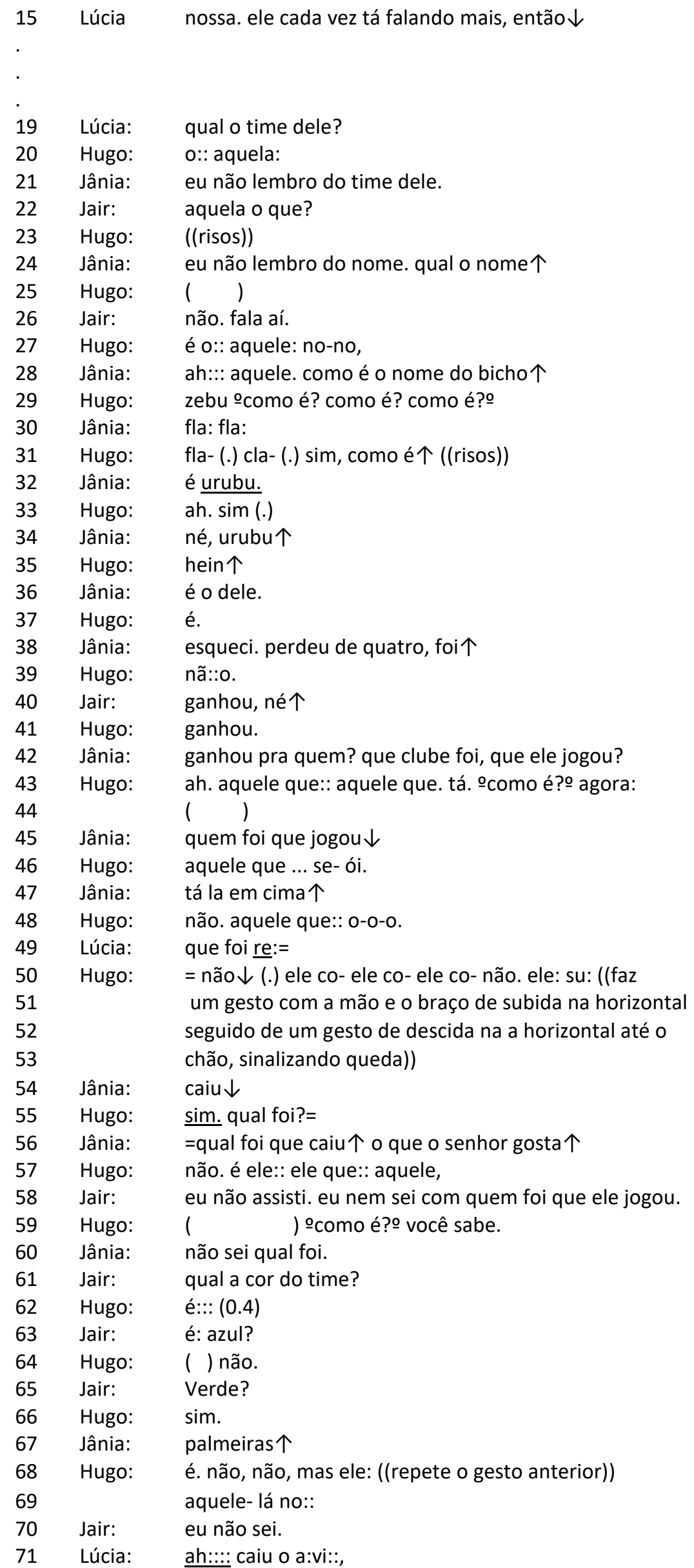




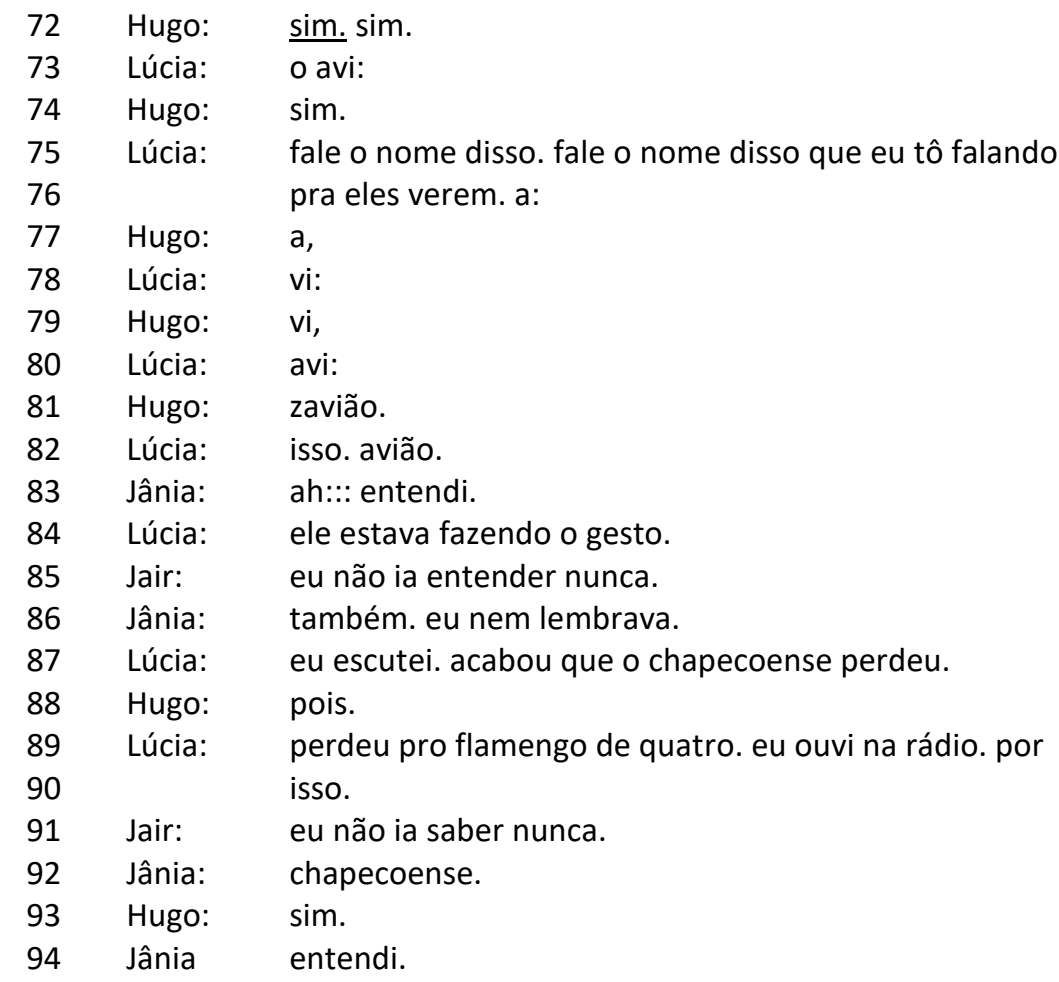

Participavam, inicialmente, da interação acima os terapeutas Jair e Jânia, e o paciente Hugo, que conversavam sobre o campeonato de futebol chamado Copa Libertadores da América até a entrada da terapeuta Lúcia na sala. Neste momento, conforme podemos verificar nas linhas 03 a 05, Jânia relata à Lúcia o tópico que estava em desenvolvimento até a chegada dela: "ele tá falando do: dos jogos, ele veio falar que o botafogo perdeu essa semana. (.) ai ele. saiu, num foi $\uparrow$ da libertadores $\downarrow$ ". A ação de Jânia se configura como um prestação de contas (cf. HERITAGE,1984) à Lúcia sobre o que estava ocorrendo no setting terapêutico na ausência dela, o que faz emergir ali os papéis institucionais de terapeuta-discente e terapeuta-docente, sendo que o contexto institucional no interior do qual tais papéis emergem se trata de uma consulta fonoaudiológica em uma clínica escola de uma universidade.

Na linha 19, Lúcia se engaja efetivamente na interação em curso ("qual o time dele?"), sendo essa inserção de uma nova participante autorizada pelos demais interlocutores nos revezamentos de turnos das linhas 20 à 33 em busca da resposta à pergunta de Lúcia. Hugo profere uma tentativa inicial de resposta "o:: aquela:", que, a princípio, é rejeita por Jânia e Jair nas linhas 21 ("eu não lembro do time dele.") e 22 ("aquela o que?"), respectivamente, como uma forma de estimulá-lo a conseguir ele próprio encontrar um caminho para se expressar. O riso de Hugo no turno seguinte sinaliza que ele reconhece a ação dos terapeutas na busca da autonomia discursiva dele ao se recusarem a falar por ele. Mesmo que convidados a falar pelos afásicos, não cabe aos fonoaudiólogos oferecer a palavra que o afásico não consegue proferir, mas sim fazer perguntas que podem os auxiliar nessa busca pela palavra e os encorajar a continuar a busca eles mesmos (LAAKASO, 2015). 
Na linha 27, Hugo assume a responsabilidade pela resposta, ratificando a autonomia a ele conferida pelos terapeutas ao iniciar a construção da sua resposta: "é o:: aquele: no-no,". Uma vez tendo Hugo iniciado a construção do turno e se deparado com as suas limitações linguísticas no que diz respeito à expressão verbal, Jânia interveio consecutivamente, na linha 28, mediando tal construção ("ah::: aquele. como é o nome do bicho $\uparrow "$ "), fazendo uma pergunta que poderia ajudá-lo a encontrar a palavra que almejava ou até mesmo sugeria uma substituição de termos (o nome do time pelo nome do animal que o simboliza). Uma vez que, a partir da perspectiva aqui adotada, a fala do afásico é investigada em interação com as falas de seus interlocutores, é interessante observar no movimento dos terapeutas discentes (i) uma concessão de espaço para o paciente tentar construir o seu turno de resposta, ao invés de tentar imediatamente falar (responder) por ele ou fornecer recursos para facilitar sua produção; bem como (ii) o reconhecimento do momento mais adequado para a intervenção terapêutica de caráter cooperativo - o momento após a tentativa do paciente. Beneficiandose da intervenção da terapeuta, Hugo, na linha 29 , tenta novamente construir a resposta solicitada pela pergunta de Lúcia ao responder à intervenção de Jânia no turno anterior -"zebu ocomo é? como é? como é?o" - usando o nome do animal que representa o time, conforme sugerido por Jânia. Nesse momento, ele incorre em uma substituição de termos (urubu por zebu), que a literatura afasiológica trata como uma parafasia semântica. No caso de Hugo, a parafasia pode ser considerada um efeito sistêmico da sua dificuldade linguística de encontrar a palavra que deseja falar. No turno seguinte à produção de Hugo, Jânia não apontou o erro do paciente e sim, na linha 30 , tentou um novo caminho para se chegar à reposta almejada, que consistiu no fornecimento do prompt silábico da palavra flamengo ("fla: fla:") a fim de que ele conseguisse enunciá-la. Todavia, diante da dificuldade de Hugo na linha 31 ("fla- (.) cla- (.) sim, como é个"), Jânia forneceu o candidato à resposta na linha 32 - "é urubu." - que é confirmada no turno seguinte por Hugo - "ah. sim" (linha 33).

Podemos verificar que a decisão de Jânia de não insistir mais na busca pela resposta foi bastante acertada, pois, caso contrário, ela estaria realçando a dificuldade dele, o que o situaria no self de incompetente/incapaz. Conforme procedeu a interação, podemos assumir que houve uma construção conjunta/ colaborativa da resposta em que a terapeuta forneceu um candidato à resposta e o paciente afásico confirmou tal resposta no turno seguinte (cf. GOODWIN, 2004). Desse modo, cabe destacar que as ações terapêuticas podem colocar ou retirar o paciente afásico do lugar de incapaz e incompetente a ele designado pela sociedade, além de poder projetar para ele um self de participante ativo ou passivo a depender das intervenções (cf. MERLINO, 2018). Obviamente, a partir de uma visão construcionista de self, cabe ao paciente ratificar ou retificar as projeções terapêuticas acerca do seu self. Hugo, por sua vez, sempre se mostra proativo na interação, nunca desistindo de construir sua resposta e nunca dizendo que não sabe, ação esta bastante comum de advir de pacientes afásicos.

Como veremos, a conversa prossegue e a terapeuta Jânia não desiste de conferir autonomia a Hugo na construção de suas repostas. Na linha 45, ela (Jânia) solicita que ele forneça o nome do time que jogou contra o flamengo ("quem foi que jogou $\downarrow$ "), por eles referido 
por urubu, no caso, animal símbolo do time. Novamente, na construção da sua resposta, Hugo se depara com as suas limitações linguísticas ("aquele que ... se- ói."), linha 46, e ("não. aquele que:: o-o-o."), linha 48. Mas, é interessante notar que ele não desiste, realçando sua proatividade ao recorrer ao gesto para se expressar, como veremos no turno das linhas 50 a 53, em que ele tenta uma produção verbal ("não $\downarrow$ (.) ele co- ele co- ele co- não. ele: su:") e, diante da impossibilidade de alcançar sua completude, se engaja em uma expressão não verbal com gestos que sinalizam a subida de algo seguida por uma queda. A produção de Hugo disparou uma inferência realizada por Lúcia na linha 71 ("ah:.:.: caiu o a:vi::,"), por ele confirmada no turno seguinte, linha 72, ("sim. sim.") de modo enfático, como pode ser verificado pelo sublinhado no primeiro sim, que sinaliza ênfase, e pela repetição do sim. Com certeza, ao construir tal inferência, Lúcia levou em conta sobretudo o gesto (recurso do aparato performático dos atores sociais, segundo Goffmann, [1959] 2008), mas também o seu conhecimento acerca da tragédia que ocorreu com o avião do time chapecoense e a informação presente em um turno anterior de que a cor do time é verde (ou seja, levou em conta o contexto sequencial). A construção dessa inferência só foi possível devido a habilidade pragmático-interacional de Hugo de recorrer a recursos semióticos não verbais que o auxiliem a expressar o que queria dizer; performance esta que reforça de forma brilhante sua identidade de falante competente. É louvável o seu empenho em fazer com que o outro o compreenda, em não admitir que a afasia o silencie. Conclui-se que, nessa interação, a construção de sentidos contou sobremaneira com a competência de Hugo, que recorreu a recursos semióticos multimodais, e foi favorecida pelo contexto sequencial, o que nos autoriza assumir que o sentido foi construído turno a turno. Assim sendo, podemos advogar que é na organização sequencial que emergem as possibilidades simbólicas de gestos e falas (GOODWIN, 2003), uma vez que, na busca do afásico pela palavra, o gesto adquire significado em virtude do contexto sequencial de sua ocorrência (cf. GOODWIN, 1986).

Excerto 3: gesto associado a palavra, contexto sequencial, máxima da relevância e perífrase verbal

$\begin{array}{lll}001 & \text { Jânia: } & \text { o peixe que o senhor gosta } \uparrow \\ 002 & \text { Hugo: } & \text { hein } \uparrow \\ 003 & \text { Jânia: } & \text { o peixe que o senhor gosta, } \\ 004 & \text { Hugo: } & \text { eu é::: ... o comoo co co- é ::: vim- tudo } \downarrow \text { tudo } \downarrow \\ 005 & \text { Jânia: } & \text { todos. } \\ 006 & \text { Hugo: } & \text { esse que tem aquele:: aquele::- ócomo é?o ( ) } \\ 007 & & \text { hoje eu tomei, eu já tomei,já botei, ((aponta para a } \\ 008 & & \text { sua boca)) } \\ 009 & \text { Jânia: } & \text { comeu hoje } \uparrow \\ 010 & \text { Hugo: } & \text { sim. } \\ 011 & \text { Jânia: } & \text { sardinha? } \\ 012 & \text { Hugo: } & \text { não,é porque tem uns que é na na:: ca:- (.)na na:: } \\ 013 & & \text { carne } \downarrow \text { por dentro. ((realiza um gesto com as mãos } \\ 014 & & \text { como se as pontas dos dedos da mão esquerda se } \\ 015 & & \text { inserissem na palma da mão direita)) <como é que } \\ 016 & & \text { chama?> }\end{array}$




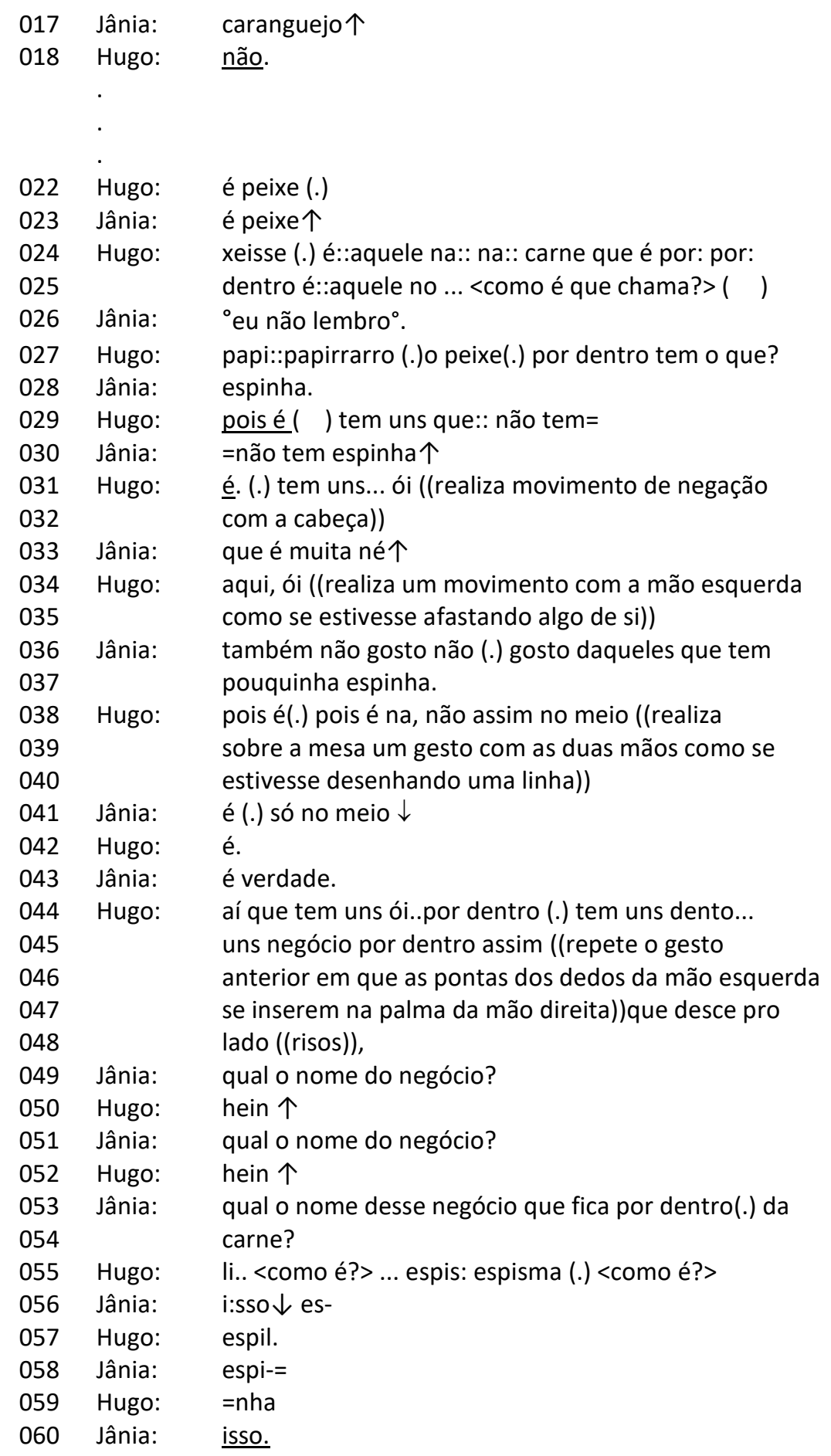

No início da interação terapeuta-paciente em uma outra sessão fonoaudiológica em grupo, conforme podemos verificar no excerto acima, Jânia propõe um tópico discursivo ("o peixe que o senhor gosta $\uparrow^{\prime \prime}$ na linha 01 . Nessa proposta, observa-se a apresentação de Jânia como terapeuta ao iniciar a interação e ao introduzir (e de certo modo, determinar) o tópico a ser desenvolvido bem como a projeção do papel de paciente para Hugo, levando-se em conta o enquadre interacional (cf. TANNEN, WALLAT, [1987] 2002) ali estabelecido - terapia fonoaudiológica - e os papéis institucionais operantes nesse tipo de enquadre. Por 
conseguinte, na linha 04, Hugo responde à Jânia ("eu é::: ... ocomoo co co- é ::: vim- tudo $\downarrow$ tudo $\downarrow$ "), assumindo o papel a ele projetado e, ao fazer isso, depara-se com suas limitações linguísticas, sendo que, diante delas, realiza dois autorreparos (cf. OLIVEIRA, DIAS, 2018), iniciados por autointerrupções abruptas. Na finalização dos autorreparos, Hugo apresenta a reposta solicitada ("tudo $\downarrow$ tudo $\downarrow$ "), que também é reparada por Jânia no turno seguinte, linha 05 : "todos.".

Embora tenha apresentado a resposta a Jânia, Hugo enfrenta suas dificuldades para se expressar indo adiante na construção de um novo turno de resposta. Não obstante a ininteligibilidade da sua fala, ele não desiste de fornecer uma resposta mais precisa à sua parceira interacional, além de solicitar sua cooperação na construção desse novo turno de reposta, linhas 06 a 08 - "esse que tem aquele:: aquele::- ocomo é?o ( ) hoje eu tomei, eu já tomei,já botei, ((aponta para a sua cavidade oral))". No turno seguinte, Jânia apresenta uma proposta de tradução da fala afásica, ou seja, uma interpretação da construção de Hugo que associa o verbo botar ao gesto de apontar para a sua cavidade oral, fornecendo um candidato a resposta

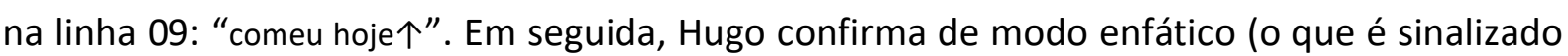
pelo sublinhado) a tradução de sua fala, que, por sua vez, dá mostras do engajamento da terapeuta na coconstrução de sentidos (cf. GOODWIN, 1995) naquela interação na linha 10 "sim.".

É muito interessante observar que a grande limitação linguística que a afasia impôs à fala de Hugo não fez com que ele se abdicasse do seu papel de falante ${ }^{7}$, uma vez que, diante de momentos de dificuldade de encontrar a palavra que queria dizer, ele recorreu ao gesto associado à palavra que conseguiu proferir em substituição a comer (botei). Essa associação de recursos verbais e não verbais, por um lado, mostra que ele reconhece que o verbo que conseguiu proferir (botar) sem a associação do referido gesto não possibilita a construção do sentido por ele almejado; por outro lado, sinaliza que nessa performance, Hugo, um sujeito afásico, não pretende se projetar como incapaz de responder ao seu interlocutor, portanto, como linguisticamente incompetente. No abando do self de incapaz/ incompetente, Hugo exibe suas habilidades pragmático-interacionais.

Até esse momento da interação em que a terapeuta intervém cooperativamente na construção do turno de Hugo, ele ainda não tinha especificado qual era o peixe que ele gostava em resposta à pergunta inicial da terapeuta. Assim sendo, na linha 11, ela intervém novamente, buscando tal especificação por meio de uma oferta de um candidato à resposta que consiste em um tipo de peixe ("sardinha?"). No turno seguinte, Hugo se engaja na construção de sua resposta: "não, é porque tem uns que é na na:: ca:- (.)na na:: carne $\downarrow$ por dentro. ((realiza um gesto com as mãos como se as pontas dos dedos da mão esquerda se inserissem na palma da mão direita)) <como é que chama?>" - linhas 15 e 16. Nessa construção, novamente, Hugo se viu diante de um episódio de dificuldade de encontrar palavra, e, diante dessa dificuldade, recorreu outra vez ao seu aparato performático e fez uso de um gesto que reforçava para a sua interlocutora que

\footnotetext{
${ }^{7}$ Para uma visão interacional acerca dos desdobramentos dos papéis de falantes, ver Goffman ([1979] 2002).
} 
a palavra que ele não conseguia encontrar possui o atributo de ser interno a algo (possivelmente, ao peixe).

Destaca-se nesse trecho a grande competência comunicativa de Hugo ao selecionar a palavra "dentro" associada ao referido gesto em referência à resposta pretendida que veremos nas próximas linhas desta análise. Mas, antes disso, também cabe destacar duas outras estratégias de caráter performático de Hugo que realçam sua expertise pragmáticointeracional. A primeira diz respeito ao fato de como ele construiu sua referência ao item lexical peixe, uma vez que, na linha 12 , valendo-se do contexto sequencial, que possibilita à interlocutora realizar inferências acerca do não dito, e amparado pela máxima da relevância (cf. GRICE, 1982), ele refere-se ao peixe com a mera menção do termo "uns". A outra consiste no uso por ele de perífrase em substituição a uma palavra que não conseguia proferir dada suas limitações linguísticas, que ocorreu nas linhas 12 e 13 ("na:: carne $\downarrow$ por dentro."). Tal perífrase, também levando em consideração o contexto sequencial, pode ser parafraseada por: aquilo que tem dentro da carne do peixe. Após a perífrase, Hugo solicitou a ajuda da terapeuta para encontrar a palavra que ele queria proferir ("<como é que chama?"), exibindo o caráter proativo da sua participação na interação.

No turno seguinte ao da perífrase, a interlocutora de Hugo, em uma tentativa de cooperação com o sucesso da construção de sentidos, fornece um termo opcional a Hugo

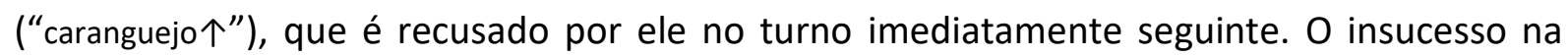
oferta da terapeuta fez com que Hugo retomasse a tentativa de encontrar a palavra que almejava por meio da cooperação da terapeuta ("xeisse (.) é:: aquele na:: na:: carne que é por: por: dentro é::aquele no ... <como é que chama?>") - linhas 24 e 25. Nesse momento, inverteu-se, de modo muito interessante, os papéis dos participantes, uma vez que Hugo passou a realizar intervenções de cunho investigativo direcionadas à terapeuta. Era ela que teria, a partir desse momento, que responder às intervenções de Hugo, ao invés de ele responder às suas intervenções. Tais inversões de papéis ilustra de um modo sobremaneira interessante a proposta da intervenção terapêutica em curso de tornar as interações paciente-terapeuta o mais simétricas possíveis em termos interacionais. Cabe destacar que a relação paciente e terapeuta, tradicionalmente, é concebida como internacionalmente assimétrica, com forte ênfase nas ações do terapeuta; no entanto, análises de ocorrências naturais de intervenções terapêuticas (como as deste estudo) podem realçar o papel relevante desempenhado por pacientes afásicos (MERLINO, 2018).

Novamente, a terapeuta não obteve sucesso em ajudar Hugo na busca pela palavra, sendo que sua resposta na linha 26 (" ${ }^{\circ}$ eu não lembro.") mostra que ela ainda não havia compreendido a fala dele (associada a gestos e no formato de perífrase) até que ele, no turno seguinte, na linha 27, após o que parece ter sido duas tentativas de proferir a palavra alvo ("papi::papirrarro"), produz um enunciado mais inteligível ("o peixe(.) por dentro tem o que?") que possibilita a interpretação adequada da parte da terapeuta. Ela, na linha 28 , diante da nova solicitação de cooperação, fornece, enfim, a tão almejada palavra ("espinha"). A resposta da terapeuta à pergunta de Hugo é, enfim, confirmada por ele na linha seguinte (29) de um modo 
enfático, conforme sinalizado pelo sublinhado ("pois é"). Podemos atribuir tal ênfase à satisfação de Hugo por ter alcançado seu objetivo comunicativo após alguns turnos de trabalho interacional de busca pela palavra que ele não conseguia dizer.

Após a resposta satisfatória da terapeuta, Hugo deu continuidade à interação, prosseguindo com a construção do seu turno, demonstrando reconhecer que a resposta apropriada à pergunta inicial da terapeuta ("peixe que o senhor gosta $\uparrow$ ") ainda não tinha sido por ele apresentada. Hugo prossegue se referindo ao fato de que tem uns peixes que tem espinha e tem outros que não tem, mostrando, por meio de gestos, não gostar daqueles que tem espinha. Desse modo, ele responde por via de referências e inferências à pergunta inicial, possibilitando à terapeuta interpretar que os peixes que ele gosta são aqueles que não têm espinhas. Não há como não enfatizar a grande expertise de Hugo de, com poucas palavras, dizer muito além das palavras (através de processos de referenciais e inferenciais) por poder contar com a preservação da sua habilidade pragmático-interacional que atuou favoravelmente na apresentação do seu self de falante competente que não pode falar.

\section{Considerações finais}

Alinhando à tese de Charles Goodwin de que o afásico é um falante competente que não pode falar, este estudo, a partir de análises de dados naturais de fala em interações face a face, trouxe ricas ilustrações (através dos próprios dados) que exibem claramente que a competência de um falante vai muito além da sua capacidade de usar a fala para se comunicar. Embora os comprometimentos linguísticos do sujeito deste estudo e do afásico estudado por Goodwin sejam distintos em termos do grau de severidade em que a expressão verbal fora afetada, ambos os comprometimentos impuseram limitações significativas à fala dos afásicos e acabaram por realçar suas competências. Nesse momento em que perde-se a fala em decorrência de acometimentos neurológicos, tem-se realçado a real competência comunicativa de um sujeito, que, na ausência da afasia, poderia ser ofuscada uma vida inteira pela fala. Os afásicos, então, concedem a nós linguistas e fonoaudiólogos a oportunidade de melhor conhecer a fala, a língua e a linguagem em suas ausências ou limitações.

Talvez, um estudioso/ pesquisador que, ao estudar as afasias, busque investigar os déficits linguísticos (o que foi comprometido linguisticamente pela afasia) esteja se furtando de (de fato) conhecer a afasia e de identificar que ela pode ser muito menos limitante do que o modo pelo qual nos é apresentada na literatura afasiológica. Olhar para as possibilidades comunicativas do sujeito afásico pode ser um caminho para mudanças paradigmáticas e, por conseguinte, no campo da fonoaudiologia, para mudanças de posturas terapêuticas.

O fonoaudiólogo que assume o objetivo de atuar na reabilitação da linguagem do afásico, investigando os déficits linguísticos por ele apresentado bem como atuando na redução dos mesmos, pode acabar por alocar o afásico no lugar de incompetente (pois nele só vê déficits/incompetências), quando, na verdade, muitas vezes, ele não é. Por outro lado, 
o fonoaudiólogo que não torna os déficits linguísticos do afásico relevantes em sua intervenção, pois tem um olhar voltado para as suas possibilidades comunicativas, consegue melhor enxergar o quão competente esses sujeitos podem ser e melhor auxiliá-los a usar suas competências a favor do sucesso da comunicação.

Como vimos nesse artigo, os afásicos almejam e reivindicam esse lugar de falante competente mesmo não conseguindo falar e, quando encontram esse espaço, concedido por terapeutas que a eles conferem autonomia na interação, têm a oportunidade de mostrar o quão competente podem ser. No caso específico deste estudo, o sujeito afásico se empenhou a todo o momento em fazer com que seus interlocutores o compreendessem, valendo-se de diversos recursos semióticos multimodais que o retiravam do silêncio, recusando o self de falante incompetente. Através do sucesso obtido nas construções conjuntas de sentidos, o afásico se projetava como falante competente. Em suas performances como falante competente, suas ações deram mostras de sua grande autonomia e proatividade, indispensáveis à sua evolução clínica e que encontraram espaço na postura teórico-prática assumida pelos terapeutas. Vestido com diversas estratégias discursivas cujos efeitos retóricos justificam sobremaneira as suas escolhas, o participante afásico deste estudo, nos termos goffmanianos, deu um show que envolveu a plateia.

Por fim, cabe fazer uma ressalva em relação às limitações impostas pelas afasias: assumir a grande competência pragmático-interacional dos afásicos com a qual eles contam para se fazerem entender na impossibilidade de usar a fala não implica de forma alguma, obviamente, afirmar que eles mantêm todas as habilidades comunicativas de alguém que pode falar (GOODWIN, 2003).

\section{Referências}

BASTOS, L. C. Interação, múltiplas semioses e corpo: uma interlocução com Charles Goodwin. Calidoscópio, v. 8, n. 2, p. 99-102, 2010. https://doi.org/10.4013/cld.2010.82.02

BAUMAN, R. Story, performance and event. In: BAUMAN, R. Contextual studies of oral narratives. Cambridge: Cambridge University Press, 1986. p. 1-10.

https://doi.org/10.1017/CBO9780511620935

COULON, A. Etnometodologia. Petrópolis: Vozes, 1995.

De FINA, A. Indentity in narrative: a discourse approach. In: De FINA, A. Identity in Narrative: A Study of Immigrant Discourse. Amsterdam: John Benjamins, 2003 . p. 11-30. https://doi.org/10.1075/sin.3

GARFINKEL, H.; SACKS, H. On formal structures of practical actions. In: GARFINKEL, H. (Org.). Ethnomethodological Studies of Work. London: Routledge \& Kegan Paul, 1986. p. 160-193.

GOFFMAN, E. A representação do eu na vida cotidiana. 15. ed. Petrópolis: Editora Vozes, 2008. 
GOFFMAN, E. Footing. In: RIBEIRO, B. T.; GARCEZ, P. M. (Orgs.) Sociolinguística Interacional. 2. ed. São Paulo: Edições Loyola. 2002 [1979]. p. 107-148.

GOODWIN, C. A Competent Speaker Who Can't Speak: The Social Life of Aphasia. Journal of Linguistic Anthropology, v. 14, n. 2, p. 151-170, 2004.

https://doi.org/10.1525/ilin.2004.14.2.151

GOODWIN, C. Conversational Frameworks for the Accomplishment of Meaning in Aphasia. In: GOODWIN, C. (Org.), Conversation and Brain Damage. Oxford: Oxford University Press, 2003. p. $90-116$.

GOODWIN, C. Producing Sense with Nonsense Syllables: Turn and Sequence in the Conversations of a Man with Severe Aphasia. In: FOX, B.; FORD, C.; THOMPSON, S. The Language of Turn and Sequence. Oxford: Oxford University Press, 2002, p. 56-80.

GOODWIN, C. Co-constructing Meaning in Conversations with an Aphasic Man. Research on Language and Social Interaction, v. 28, p. 233-60, 1995.

https://doi.org/10.1207/s15327973rlsi2803 4

GOODWIN, C. Audience diversity, participation and interpretation. Text, v. 6, n. 3, p. 283-316, 1986. https://doi.org/10.1515/text.1.1986.6.3.283

GRICE, H. P. Lógica e Conversação. In: DASCAL, M. Fundamentos Metodológicos da Linguística. Pragmática. Campinas: Unicamp, 1982. p. 81-104.

GUMPERZ, J. J. Discourse strategies. Cambridge: Cambridge University Press, 1982. https://doi.org/10.1017/CBO9780511611834

GUMPERZ, J. J. On Interactional sociolinguistic method. In: SARANGI, S.; ROBERT, C. Talk, work and institutional order. New York: Mouton Gruyter, 1999. p. 453-471. https://doi.org/10.1515/9783110208375.4.453

GUMPERZ, J. J. Convenções de Contextualização. In: RIBEIRO, B. T.; GARCEZ, P. M. (Orgs.) Sociolinguística Interacional: antropologia, linguística e sociologia e análise do discurso. Porto Alegre: AGE, 1998. p. 98-119.

JACOBY, S.; OCHS, E. Co-construction: an introduction. Research on Language and Social Interaction, v. 28, n. 3, p. 171-183, 1995. https://doi.org/10.1207/s15327973rlsi2803 1

KLIPPI, A. Pointing as an embodied practice in aphasic interaction. Aphasiology, v. 29, n. 3, p. 337-354, 2015. https://doi.org/10.1080/02687038.2013.878451

LAAKSO, M. Collaborative participation in aphasic word searching: comparison between significant others and speech and language therapists. Aphasiology, v. 29, n. 3, p. 269-290, 2015. https://doi.org/10.1080/02687038.2013.878450

MERLINO, S. Assisting the Client in Aphasia Speech Therapy: A Sequential and Multimodal Analysis of Cueing Practices. Hacettepe University Journal of Education, v. 33, p. 334-357, 2018. https://doi.org/10.16986/HUJE.2018038810

MOERMAN, M. Talking Culture: Ethnography and Conversation Analysis. Philadelphia: University of Pennsylvania Press, 1996 [1988].

MORATO, E. M. Da noção de competência no campo da linguística. In: SIGNORINI, Ines (Org.). Situar a linguagem. São Paulo: Parábola Editorial, 2008. p 39-66. 
OCHS, E. Constructing Social Identity: A language socialization perspective. Research on Language and Social Interaction, v. 26, n. 3, p. 287-306, 1993.

https://doi.org/10.1207/s15327973rlsi2603 3

OCHS, E.; CAPPS, L. Living Narrative: Creating Lives in Everyday Storytelling. Harvard: Harvard University Press, 2001.

OLIVEIRA, L. M. A performance de pessoas com afasia na construção de narrativas em interações face a face em grupo. Rio de Janeiro, RJ. Tese de Doutorado. Pontifícia Universidade Católica do Rio de Janeiro - PUC - Rio, 2013, 170p.

OLIVEIRA, L. M. Olhando para as trajetórias de reparo em um relato de procedimento realizado por uma pessoa com afasia durante uma conversa face a face. Cadernos do IL, v. 38, n. 38, p. 64-87, 2009.

OLIVEIRA, L. M.; BASTOS, L. C. A performance narrativa de mulheres com afasia. Revista Veredas, v. 19, p. 269-291, 2015.

OLIVEIRA, L. M.; BASTOS, L. C. Narrando em colaboração: as construções discursivas de uma pessoa com afasia. Linguagem em (Dis)curso, v. 14, n. 2, p. 247-267, 2014. https://doi.org/10.1590/1982-4017.140202.2313

OLIVEIRA, L. M.; BASTOS, L. C. Aspectos da dinâmica interacional da narração de histórias por pessoas com afasia. Calidoscópio, v. 10, n. 2, p. 194-210, 2012.

https://doi.org/10.4013/cld.2012.102.07

OLIVEIRA, L. M.; BASTOS, L. C. Uma história de AVC: a construção do sofrimento por uma pessoa com afasia. Revista Veredas, v. 15, n. 1, p. 120-135, 2011.

OLIVEIRA, L. M., DIAS, J. G. O autorreparo como estratégia adaptativa na fala em interação de um afásico. Linguagem em (Dis)curso, v. 18, n. 1, p. 49-68, 2018.

https://doi.org/10.1590/1982-4017-180103-5017

OLIVEIRA, L. M.; OLIVEIRA, M. M. O uso do discurso reportado direto por uma pessoa com afasia na construção de uma narrativa. Revista CEFAC, v. 16, n. 1, p. 131-146, 2014. https://doi.org/10.1590/1982-021620147512

SACKS, H.; SCHEGLOFF, E.; JEFFERSON, G. Sistemática elementar para a organização da tomada de turnos para a conversa. Revista Veredas, v. 7, n. 12, p. 1-67, 2005.

SACKS, H. On the preferences for agreement and contiguity in sequences in conversation. In: BUTTON, G.; LEE, J. R. E (Orgs.). Talk and Social Organization. Clevedon: Multilingual Matters, 1993, p. 54-69.

SCHEGLOFF, E. The Organization of Preference/Dispreference. Apostila do curso Conversational Structures, UCLA, 1995, p. 54-89.

SCHEGLOFF, E; JEFFERSON, G; SACKS, H. The Preference for self-correction in the organization of repair in Conversation. Language, v. 53, n. 2, p. 361-382, 1977.

https://doi.org/10.1353/lan.1977.0041

SCHIFFRIN, D. Discourse markers. Cambridge: Cambridge University Press, 1987. https://doi.org/10.1017/CBO9780511611841 
TANNEN, D. "On Talking voice that is so sweet": constructing dialogue in conversation. In: TANNEN, D. (Org.). Talking voices: repetition, dialogue and imagery in conversational discourse. Cambridge: Cambridge University Press, 1989, p. 98-133.

TANNEN, D.; WALLAT, C. Enquadres interativos e esquemas de conhecimento em interação: exemplos de um exame / consulta médica. Trad. Parmênio Camurça Citó. In: RIBEIRO, B. T.; GARCEZ, P. M. (Orgs). Sociolinguística Interacional. 2. ed. São Paulo: Edições Loyola, 2002 [1987], 153-174.

Recebido em: 25/07/2018

Aceito em: 08/11/2018 